\title{
THE RESEARCH OF THE PARAMETERS, PROPERTIES AND TYPES OF SOCIAL EXPECTATIONS OF STUDENT YOUTH
}

\section{Popovych I. S.}

\section{INTRODUCTION}

Student youth is a socially differentiated socio-demographic community that combines peculiar psycho-physiological, sociopsychological, cultural and educational dimensions that provide biosocial maturation to achieve social subjective activity. The social environment, in which the social subjective activity of student youth is carried out, is a combination of a number of conditions in which they obtain profession, gain social experience, master norms and rules of professional behaviour, social values, primary professionalization, and other important life tasks.

Entry into independent life is perhaps the most important and one of the most responsible steps of a person in life. The achievement of social subjective activity combines social and personal self-determination, which includes: identification of his/her own personality and place in the adult world. The period from 18 to 23 years old is considered as late adolescence or early maturity and is characterized by substantial mental growth. These include the rapid development of intellectual functions and the stabilization of world outlooks. The young person at this age is characterized by all-or-nothing thinking and convergent thinking, statements, and evaluations. In part, his/her communication and interaction are accompanied by confrontations with adults, ignoring their advice, experience, guidance, unrealized social expectations and hopes. The social expectations that accompany these processes and overwhelm this extremely diverse and changeable period of student life are important regulators of their behaviour.

The research of the social expectations of student youth requires us to outline the semantic psychological parameters, properties of the sociopsychological phenomenon and selection of key types of social expectations of students, which will allow for a better understanding of the representatives of this age. It is known that the desire to split achievements into types provides for any scientific research 
systematization, streamlining and multiplies the knowledge gained. Our empirical study outlines one of the options for studying the types of social expectations of student youth.

Hypothesis. We assume that the received scientific facts about the parameters, properties and types of social expectations of student youth are important socio-psychological knowledge that makes a scientific contribution to the investigated phenomenon; the application of the results obtained will facilitate the effective organization of work with student youth.

Purpose is to define psychological content parameters and properties of social expectations of student youth; to investigate types of social expectations by cluster analysis; outline the socio-psychological content of the investigated phenomenon.

\section{MATERIAL \& METHODS}

Participants. The study was attended by students of the secondfourth years of study at the higher educational establishments of Ukraine: Kherson State University (KSU), numbering 245 persons (40.56\%); Kherson National Technical University (KNTU), numbering 123 persons (20.37\%); Kremenets Regional Humanitarian and Pedagogical Academy named after Taras Shevchenko, numbering 130 (21.52\%); Volodymyr Vynnychenko Central Ukrainian State Pedagogical University (CSPU named after V. Vynnychenko), numbering 106 persons (17.55\%). The total sample population was 604 persons. The average age of sample was 20.4 years $(\mathrm{SD}=0.9$, range $18-28$ years). The sample was $68.21 \%$ women and $31.79 \%$ men.

The research is conducted according to ethical standards of committee on the rights of experiments of Helsinki declaration ${ }^{1}$.

Organization of research. An empirical cut was made during September 2017 and January 2019. The empirical research received permission and recommendations from the administrations of the faculties of universities.

Procedures and instruments. Tests with standardized questionnaires were used to measure the research parameters of the

${ }^{1}$ WMA Declaration of Helsinki. Ethical Principles for Medical Research Involving Human Subjects. URL: http://www.wma.net/es/30publications/10policies /b3/17c.pdf 
students. The questionnaire "Level of social expectations" (LSE) ${ }^{2}$ : the level of social expectations of personality $\left(\mathrm{LSE}_{\mathrm{p}}\right)$, the level of awareness of the expected events $\left(\mathrm{LAE}_{\mathrm{p}}\right)$, the level of the expected attitude towards the participants of interpersonal interaction (LEA $A_{p}$ ), the level of the expected performance $\left(\mathrm{LEP}_{\mathrm{p}}\right)$. The questionnaire "Level of subjective control" ("LSC") ${ }^{3}$ : general internality (GI), internality in the area of achievements (IA), internality in the area of failures (IF), internality in relationships (IR), internality in the area of labor relations (ILR), internality concerning health and illness (IHI). "Purpose in Life Test" ("PIL") ${ }^{4}$ : life goals (LG), process (P), result (R), locus of control - Self (LCS), locus of control - life (LCL), general awareness of life (GAL). The questionnaire "The level of aspirations of personality" ("LAP") $)^{5}$ : internal motif (IM), cognitive motif (CM), avoidance motif (AM), the motif of competition (MC), the motif of changing activity (MCA), the motif of self-respect (MS), the significance of results (SR), task complexity (TC), volitional effort (VE), estimation of the level of the achieved results (ELAR), estimation of personal potential (EPP), the projected level of mobilizing efforts (PLME), the expected level of results (ELR), regularity of results (RR), initiative (I).

The responses were evaluated by means of the bipolar semantic differential scale, its value was within the range of -3 (absolutely disagree) and +3 (absolutely agree). The indexes of reliability, obtained by means of Cronbach's alpha, were: $\alpha_{\mathrm{LSE}}=.821 ; \alpha_{\mathrm{LSC}}=.791$ : $\alpha_{\mathrm{PIL}}=.867 ; \alpha_{\mathrm{LAP}}=.721$. The sociometric method "Expectometry" coefficient of expectations (CE), expectometric status (ES), the level of adequacy of self-expectations (LS), the coefficient of reciprocally expected choices $(\mathrm{CC})$ - the reliability coefficient obtained by means of

${ }^{2}$ Попович І. С. Психологія соціальних очікувань особистості: автореф. дис. ... д-ра психол. наук : 19.00.05. Сєвєродонецьк, 2017. 40 с.

3 Rotter J. Generalized expectancies for internal versus external control of reinforcement. Psychological Monographs: General and Applied, 80(1), 1966. P. 1-28. URL : http://dx.doi.org/10.1037/h0092976

4 Леонтьев Д. А. Тест смысложизненных ориентаций (СЖО). 2-е изд. М., 2000. $18 \mathrm{c}$

${ }^{5}$ Психологическая диагностика. Методология: уровень притязаний личности. Methodology: the level of personality claims. - URL: https://sites.google.com/site/ test $300 \mathrm{~m} / 16 \mathrm{pfa}$

${ }^{6}$ Попович І. С. Психологія соціальних очікувань особистості : автореф. дис. ... д-ра психол. наук : 19.00.05. Сєвєродонецьк, 2017. 40 с. 
Cronbach's alpha statistics was $\alpha=.727$. The methods "Expected situation" and "Realization of expectations" were used to determine the characteristics of social expectations: internality/externality $\left(\mathrm{IE}_{\mathrm{p}}\right)$, activeness/passiveness $\left(\mathrm{AP}_{\mathrm{p}}\right), \quad$ openness/closeness $\left(\mathrm{OC}_{\mathrm{p}}\right)$, adequacy/inadequacy $\left(\mathrm{AI}_{\mathrm{p}}\right)$. The dichotomous scale was used, Cronbach's alpha was $\alpha=.843$. The indexes of reliability of the methods used and the tests of Cronbach's alpha were within sufficient (.7) and high levels (.9).

Statistical analysis. Statistical processing of empirical data and graphical presentation of the results were performed by means of statistical programs "SPSS" v. 23.0 or the other name PASW (Predictive Analytics SoftWare) Statistics and "MS Excel". Spearman's correlation coefficients $\left(r_{s}\right)$ were used to find and determine the correlation between the indexes obtained. The validation of the parameters of the normal distribution was done by means of a one-sample criterion of Kolmogorov-Smirnov $\lambda$. To determine the homogeneity of empirical data, factor analysis was used. The determination of the types of social expectations of student youth was carried out by cluster analysis using the $k$-means. Arithmetic mean value of minimum (min), maximum (max), parameters (M) and mean-square deviation (SD) were calculated. The differences between the values of the variables at the level $\mathrm{p} \leq .05$ are considered statistically significant.

\section{RESULTS OF RESEARCH}

\section{Research of psychological content parameters and properties of social expectations of student youth}

At the initial stage of the empirical study, using the abovementioned test standardized methods, the content parameters of social expectations of students were determined. The obtained results of the studied parameters were estimated, based on the scale of minimum (min), maximum (max), arithmetic mean (M) and square deviation (SD), which are presented in Table 1.

${ }^{7}$ Попович І. С. Психологія соціальних очікувань особистості : автореф. дис. ... д-ра психол. наук : 19.00.05. Сєвєродонецьк, 2017. 40 с.

${ }^{8}$ Там само. 
Table 1

Values of scales of the studied parameters of social expectations of students $(n=604)$

\begin{tabular}{|c|c|c|c|c|}
\hline Scale & $\begin{array}{c}\text { Minimum, } \\
\text { min }\end{array}$ & $\begin{array}{c}\text { Maximum, } \\
\max \end{array}$ & $\begin{array}{c}\text { Arithmetic } \\
\text { mean, } \mathbf{M}\end{array}$ & $\begin{array}{l}\text { Mean-square } \\
\text { deviation, SD }\end{array}$ \\
\hline \multicolumn{5}{|c|}{ "LSE" } \\
\hline $\mathrm{LSE}_{\mathrm{p}}$ & 43.00 & 92.00 & 68.65 & 12.22 \\
\hline $\mathrm{LAE}_{\mathrm{p}}$ & 11.00 & 23.00 & 18.48 & 3.29 \\
\hline $\mathrm{LEA}_{\mathrm{p}}$ & 11.00 & 18.00 & 13.72 & 1.79 \\
\hline $\mathrm{LEP}_{p}$ & 20.00 & 52.00 & 35.69 & 8.49 \\
\hline \multicolumn{5}{|c|}{ "LSC" } \\
\hline GI & 135.00 & 249.00 & 198.13 & 21.65 \\
\hline IA & 27.00 & 69.00 & 53.69 & 7.79 \\
\hline IF & 19.00 & 72.00 & 48.81 & 8.49 \\
\hline IR & 20.00 & 55.00 & 38.65 & 6.79 \\
\hline ILR & 25.00 & 52.00 & 35.64 & 5.29 \\
\hline IHI & 6.00 & 28.00 & 19.12 & 4.67 \\
\hline \multicolumn{5}{|c|}{ "PIL" } \\
\hline $\mathrm{LG}$ & 13.00 & 41.00 & 32.33 & 7.05 \\
\hline $\mathrm{P}$ & 12.00 & 41.00 & 30.11 & 5.04 \\
\hline $\mathrm{R}$ & 9.00 & 34.00 & 25.12 & 5.13 \\
\hline LCS & 8.00 & 31.00 & 21.12 & 4.00 \\
\hline LCL & 13.00 & 41.00 & 30.10 & 4.11 \\
\hline GAL & 55.00 & 129.00 & 103.12 & 14.18 \\
\hline \multicolumn{5}{|c|}{ “ $L P C ”$} \\
\hline IM & 5.00 & 19.00 & 12.00 & 2.88 \\
\hline $\mathrm{CM}$ & 8.00 & 20.00 & 14.28 & 2.66 \\
\hline AM & 4.00 & 19.00 & 11.52 & 3.12 \\
\hline $\mathrm{MC}$ & 5.00 & 20.00 & 12.60 & 2.99 \\
\hline MCA & 5.00 & 22.00 & 12.04 & 3.49 \\
\hline MS & 8.00 & 20.00 & 12.70 & 3.57 \\
\hline SR & 4.00 & 18.00 & 8.63 & 3.15 \\
\hline $\mathrm{TC}$ & 3.00 & 19.00 & 5.88 & 2.48 \\
\hline VE & 5.00 & 20.00 & 12.12 & 3.51 \\
\hline ELAR & 4.00 & 13.00 & 9.79 & 2.34 \\
\hline EPP & 9.00 & 19.00 & 13.23 & 2.69 \\
\hline PLME & 10.00 & 22.00 & 13.56 & 2.42 \\
\hline ELR & 4.00 & 15.00 & 9.56 & 2.67 \\
\hline
\end{tabular}




\begin{tabular}{|c|c|c|c|c|}
\hline Scale & $\begin{array}{c}\text { Minimum, } \\
\text { min }\end{array}$ & $\begin{array}{c}\text { Maximum, } \\
\mathbf{m a x}\end{array}$ & $\begin{array}{c}\text { Arithmetic } \\
\text { mean, M }\end{array}$ & $\begin{array}{c}\text { Mean-square } \\
\text { deviation, SD }\end{array}$ \\
\hline RR & 6.00 & 20.00 & 13.23 & 2.78 \\
\hline I & 10.00 & 20.00 & 12.02 & 2.65 \\
\hline \multicolumn{5}{|c|}{ “Expectometry” } \\
\hline CE & .07 & .86 & .45 & .17 \\
\hline ES & .00 & .57 & .23 & .12 \\
\hline LS & .25 & 1.25 & .72 & .24 \\
\hline CC & .00 & .33 & .10 & .07 \\
\hline
\end{tabular}

Note: min - minimum; max - maximum; $M$ - arithmetic mean; SD - meansquare deviation.

The next stage of the qualifying study was to carry out the contentanalytical methods "Expected Situation" and "Implementation of Expectations". The method "Expected Situation" provided a concise description of the behaviour of students in the context of solving an actual problem from the educational-professional sphere of the educational process with the help of 8-10 sentences. The sociopsychological interpretation of respondents' cognitive, emotional value, and connotative features were important in the actual social situation of the educational process, and other situations were not taken into account $(\mathrm{n}=604)$. After completing the assignment, respondents described using their 8-10 sentences the implementation of their expectations, that is, they interpreted the reproduction of social reality. The evaluation of the results is based on the minimum ( $\min )$, max (max), arithmetic mean (M) and square deviation (SD), which is presented in Table 2.

Table 2

Arithmetic mean and RMS deviations of student social expectations $(n=604)$

\begin{tabular}{|c|c|c|c|c|}
\hline Scale & $\begin{array}{c}\text { Minimum, } \\
\text { min }\end{array}$ & $\begin{array}{c}\text { Maximum, } \\
\text { max }\end{array}$ & $\begin{array}{c}\text { Arithmetic } \\
\text { mean, } \mathbf{M}\end{array}$ & $\begin{array}{c}\text { Mean-square } \\
\text { deviation, SD }\end{array}$ \\
\hline $\mathrm{IE}_{\mathrm{p}}$ & .10 & .87 & .48 & .20 \\
\hline $\mathrm{AP}_{\mathrm{p}}$ & .10 & .85 & .48 & .20 \\
\hline $\mathrm{OC}_{\mathrm{p}}$ & .20 & 1.10 & .72 & .23 \\
\hline $\mathrm{AI}_{\mathrm{p}}$ & .20 & 1.25 & .73 & .23 \\
\hline
\end{tabular}

Note: min - minimum; max - maximum; $M$ - arithmetic mean; $S D$ - meansquare deviation. 
The obtained results of content analysis allowed determining the properties of social expectations of student youth. It has been established that the prevailing expectations internality level is $20.11 \%$ of students, the state of the externality of expectations $-22.63 \%$, activeness of expectations $-22.03 \%$ of students, the state of passiveness of expectations $-24.17 \%$, openness of expectations $-37.13 \%$, mental condition of closeness of expectations - $26.01 \%$, an adequate expectation - in $42.22 \%$ and inadequate expectations - in $23.17 \%$ of the subjects. There was a manifestation of the polarity of expectations - in $12.1 \%$ and there was the ambivalence of expectations - in $2.1 \%$. Expectedly positive correlation of scales was established $\mathrm{IE}_{\mathrm{p}}$ and $\mathrm{AP}_{\mathrm{p}}$ $\left(r_{s}=0.818 ; \mathrm{p}<.01\right)$. We admit that high indicators of openness of students may be related to the aspiration of the subjects as best possible to outline the expected situation, which respectively affected the quantitative parameters of signs that characterize the future. For example, in the text under study 1 , we state the following maximum number of signs characterizing the future: B. C -13 ; D. I. -12 and T. A. -11 signs. Taking into account the age, content-specific features of the sample, we believe that the results objectively reflect this dimension of the expected social reality and are reliable. The high rates of inadequacy of social expectations of student youth alerted us in some way. We explain this by the fact that the excessive openness of expectations, the desire to get "all at once", manifestations of all-or-nothing thinking, partly biased, ill-considered position are characteristics of a significant level of inadequacy of expectations of social youth.

We come to conclusion that a strict quantization of texts, the creation of a coding matrix, quantitative and qualitative analysis, the empirical distribution of scales of all levels of the studied parameters, the definition of correlation with the parameters obtained by known techniques, provided reliability, authenticity and validity of the use of content analysis in our study.

We consider a combination of quantitative and qualitative contentanalysis and author's technique "Expectometry" (methodology for studying socio-psychological expectations) methodologically grounded. The applied examples of the socio-psychological situation in expectometry were as close as possible to the realities for all student groups that formed a sample population. This allowed predicting the behaviour of participants in the interaction, to investigate social reality, 
network of interactions in the contact group. Social reality graphically reproduced through the construction of the structure of the interpersonal relationships of the contact group, the expected network of relationships is reflected. The expected network of interpersonal relationships best reflects social reality and allows you to analyse the dynamics of group life more deeply, to compare real with the predicted events. Comparison of the expected variant and sociometric, that is, real (how the sample population act at this moment), allowed to determine the quantitative characteristics of the expected election that coincided with sociometric, and the number of expectations of their own choice. An important content psychological parameter of studying social expectations of student youth is the level of adequacy of self-expectations. This parameter reflects the important and original content of the investigated phenomenon of personality, aimed at oneself. Self-expectations, selfevaluation, evaluation of actions and behaviour of oneself, evaluation of actions and behaviour of others, the attitude towards oneself and others are the core components of the expected attitude of a person to the others with whom he or she interacts. Self-evaluation has high assimilative ability, in comparison with other factors of social expectations. They are difficult to change, "move" - it is a result of permanent work of social expectations, a qualitative and quantitative indicator of permanent testing acts. Self-evaluation attitude has a regulatory impact on the level of social expectations through the internalization and exteriorization of self-evaluation in various fields of life. It is known that some researchers consider self-evaluation attitude to be the expected attitudes ${ }^{9}$. Internal processes promote the assimilation of external social patterns of behavioural acts, group norms, human relationships and their transformation into internal mental formations, subjective representations, and individual norms ${ }^{10}$. External processes carry out inverse transformations. These two processes are mutually agreed, have high regulatory capacity, and have a cardinal effect on the content and dynamic parameters of self-assessing attitudes, in particular on the level of social expectations. We have found out that it is in this

9 Осадько О. Ю. Соціальні очікування учнів щодо педагога-професіонала та рефлексування цих очікувань вчителями. Українська психологія: сучасний потенціал : зб. наук. праць: В 3 т. К., 1996. Т. 2. С. 284-293.

${ }^{10}$ Бобнева М. И. Социальные нормы и регуляция поведения: монография. М., $1978.311 \mathrm{c}$. 
interdependence that the locus of control is emerging as the most important psychological mechanism. "Technological", that is, the procedural component of the formation of social expectations of the subject of interaction depends on the localization of control.

During the study, we analysed the vast amount of discourses created by the sample population. The texts are analysed from the specially organized socio-psychological situations, from everyday practice, in particular the conversations of the participants of interpersonal interaction that take place in everyday situations. Obviously, the discourse analysis is implemented in the context of the study of the problem of social expectations of an individual. The analysis of discourses returns us to the psycholinguistic diagnosis of individual cognitive space, which is a unique combination of all knowledge and ideas of man as a whole person ${ }^{11}$. Further statistical analysis is performed according to the data of only those respondents whose answers had a full description of social expectations and behaviour in the current situation $(n=604)$.

We believe that the proposed set of 39 psychological parameters is methodologically grounded, which reflects the subject of study of psychological content parameters and properties of social expectations of student youth. The names of the scales reflect the essence of the research parameter. We will explain the similar scales: $L_{\mathrm{s}}-$ measures the notion about oneself as a strong individual possessing sufficient freedom of choice; $\mathrm{LC}_{1}$ - measures an individual's ability to control his life, make decisions easily and implement them in life. There are similar parameters, determined by means of different tests: the level of the expected performance $\left(\mathrm{LEP}_{\mathrm{p}}\right)$ and the expected level of results (ELR). Let's proceed to the next part of the empirical study - clusterization of types of social expectations of student youth.

\section{Research and characterization of types of social expectations of student youth}

For the first time cluster analysis as a method has been applied in the sociological science. The name "cluster analysis" comes from the English word "cluster" - bunch, accumulation. The researcher R. Tryon first identified the subject of cluster analysis, revealed the essence and

\footnotetext{
11 Заасєкіна Л. В. Психолінгвістична діагностика. Луцьк, 2008. 188 с.
} 
submitted the methodology of application ${ }^{12}$. Cluster analysis is a statistical procedure that performs a multidimensional classification of data that contains information about a sample of objects, that is, cluster analysis organizes objects in relatively homogeneous groups ${ }^{13,14,15}$. The cluster analysis by the $k$-means clustering consists in combining the parameters by the individual factors into statistical homogeneous groups-clusters. The purpose of the method is to divide $n$ measurements into $k$ clusters so that each dimension of the studied persons belonged to a cluster with the nearest mean value. The method is based on minimizing the sum of squares of distances between each observation and the centre of its cluster, that is, the function (see formula 1):

$$
\sum_{i=1}^{N} d\left(x_{i}, m_{j}\left(x_{i}\right)\right)^{2}
$$

where $d$-metric; $x_{i}$ - object of data; $m_{j}\left(x_{i}\right)$-center of the cluster, which is assigned an element $x_{i}$ on the $\mathrm{j}$ - iteration.

Simplicity, speed of execution and expediency of application for clusterization of a large number of observations $(n=604)$ have induced us to choose the cluster analysis by means of the $k$-means clustering in determining the types of expectations of the sample population. After analysing a huge volume of data, it seems logical to combine the investigated parameters of social expectations of the individual into organized complexes of investigated indicators, that is, visual taxonomy. A feasible option for such taxonomy is the cluster analysis by the $k$-means clustering, which consists in combining the parameters by individual factors into statistical homogeneous groups - clusters.

Cluster analysis is an indispensable method of classifying large amounts of information on groups that are suitable for further analysis. Cluster analysis by the $k$-means clustering gives the most probable and significant solution. The implementation of our cluster analysis is

${ }^{12}$ Tryon R. C. Cluster analysis. London, 1939. 139 p.

${ }^{13}$ Lloyd S. Least square quantization in PCM's. Bell Telephone Laboratories Paper, 1957. P 211-227.

14 Попович I. С. Визначення типів соціальних очікувань методом кластерного аналізу. Науковий вісник Херсонського державного університету. Серія : психологічні науки : зб. наук. праць ХДУ / за ред. О. Є. Блинової. Херсон, 2017. Вип. 1. Т. II. С. 160-166.

${ }^{15}$ Попович І. С. Психологія соціальних очікувань особистості : автореф. дис. ... д-ра психол. наук : 19.00.05. Сєвєродонецьк, 2017. 40 с. 
realized in several stages. At the preparatory stage, empirical data were obtained $(n=604)$. At the second stage, data were prepared for clustering. An important methodological value was the choice of studied indicators, which would be carried out by clustering. We selected the following list of investigated indicators that were applied in the cluster analysis: the level of social expectations of personality $\left(\mathrm{LSE}_{\mathrm{p}}\right)$, general internality (GI), general awareness of life (GAL), the projected level of mobilizing efforts (PLME), the expected level of results (ELR), indicators of the properties of social expectations on dichotomous scales: internality/externality $\left(\mathrm{IE}_{\mathrm{p}}\right)$, activeness/passiveness $\left(\mathrm{AP}_{\mathrm{p}}\right)$, openness/ closeness $\left(\mathrm{OC}_{\mathrm{p}}\right)$, the coefficient of expectations $(\mathrm{CE})$. The selected list of nine features is considered methodologically grounded and one that fully determines the content of subject of the research. Of course, the established social and psychological content of expectations will depend on the determined features. We have applied the level of social expectations as the main feature that is basic and combines two psychological dimensions: personal and social. Thus, four characteristics that characterize the socio-psychological determinants of personality expectations are selected, and the following four characteristics characterize social expectations as an important factor in constructing the social reality by personality. Such a methodology of cluster analysis allowed taking into account the same number of parameters of personal and social dimensions of research of social expectations of an individual. Then the objective reflection of the content features in the following clusters is calculated. Of course, we used the levels of social expectations of students as a basic measure. Only in the third stage, we were convinced that it would be most rational in our version to apply a cluster analysis by the $k$-means clustering. After that, the next step was to distribute $n$ measurements of the studied persons on $k$ clusters so that each measurement of the studied person belonged to the cluster with the nearest mean value. It should be noted that one of the requirements that the researcher must withstand is the minimum allowable number of respondents' measurements in the cluster - in our version $n \geq 43$. Equally important requirement was to withstand the randomness and homogeneity of the sample population. Homogeneity was established with the help of "SPSS" v. 23.0 by the reduction of interdependence, using factor analysis. It has been established that the Kaiser-MeyerOlkin (KMO) Test (a measure of sample adequacy) is .659 (a cluster 
analysis should be used when the number is higher than .5), which is a positive result. Bartlett's test of sphericity is $(\mathrm{p}<.001)$. This allowed us to apply cluster analysis reasonably. Then by the method of samples the optimal number of clusters is set to five. The level of social expectations of personality (LSEp), the basic parameter of our study is defined by the first object of clusterization, which we considered as the centre of the first cluster, the second - the second, etc. We believe that it is methodologically grounded to start the cluster research and establish the beginning of clusterization from the level of social expectations. Let's show the starting centres of the clusters in the table 3 .

Table 3

Starting Cluster Centres $(\mathbf{n}=\mathbf{6 0 4})$

\begin{tabular}{|c|c|c|c|c|c|}
\hline $\begin{array}{c}\text { Para- } \\
\text { meters }\end{array}$ & $\begin{array}{c}\text { Cluster 1 } \\
(\mathbf{n = 4 9})\end{array}$ & $\begin{array}{c}\text { Cluster 2 } \\
(\mathbf{n = 5 8})\end{array}$ & $\begin{array}{c}\text { Cluster 3 } \\
(\mathbf{n = 9 2})\end{array}$ & $\begin{array}{c}\text { Cluster 4 } \\
(\mathbf{n = 2 6 3})\end{array}$ & $\begin{array}{c}\text { Cluster 5 } \\
(\mathbf{n = 1 4 2})\end{array}$ \\
\hline $\mathrm{LSE}$ & 94 & 83 & 82 & 71 & 48 \\
\hline $\mathrm{GI}$ & 265 & 135 & 227 & 208 & 153 \\
\hline $\mathrm{GAL}$ & 123 & 124 & 47 & 155 & 61 \\
\hline $\mathrm{PLME}$ & 20 & 14 & 20 & 18 & 11 \\
\hline $\mathrm{ELR}$ & 9 & 14 & 14 & 15 & 3 \\
\hline $\mathrm{IE}_{\mathrm{p}}$ & .82 & .64 & .69 & .64 & .14 \\
\hline $\mathrm{AP}_{\mathrm{p}}$ & .81 & .66 & .61 & .56 & .16 \\
\hline $\mathrm{OC}_{\mathrm{p}}$ & 1.00 & 1.00 & 1.00 & 1.00 & .60 \\
\hline $\mathrm{CE}$ & .18 & .70 & .16 & .54 & .41 \\
\hline
\end{tabular}

An important feature of the $k$-means clustering is that as a result of optimization, the differences between objects of the same cluster become insignificant, and of different clusters become significant. Determining the starting centres of clusters is a prerequisite for establishing the minimum differences between the investigated parameters of one cluster. Let us show the final cluster centres in table 4.

The establishment of final cluster centres shows the boundaries of a range of investigated indicators that are assigned to a particular cluster. We consider it necessary to characterize the received clusters.

The received clusters are an embodiment of a visual taxonomy. The sequence of the studied indicators testifies that after the level of social expectations in our priority there is a vertical dimension for us - the socio-psychological determinants of expectations of personality, and 
then the studied indicators of social expectations are located as a factor in constructing of social reality by personality. We will conduct the analysis of results in the specified sequence, taking into account social and personal and interpersonal characteristics. Let's give a description of the clusters received, based on the average values and the mean square deviations of parameters.

Final Cluster Centres $(n=604)$

\begin{tabular}{|c|c|c|c|c|c|}
\hline $\begin{array}{c}\text { Para- } \\
\text { meters }\end{array}$ & $\begin{array}{c}\text { Cluster 1 } \\
(\mathbf{n = 4 9})\end{array}$ & $\begin{array}{c}\text { Cluster 2 } \\
(\mathbf{n = 5 8})\end{array}$ & $\begin{array}{c}\text { Cluster 3 } \\
(\mathbf{n = 9 2})\end{array}$ & $\begin{array}{c}\text { Cluster 4 } \\
(\mathbf{n = 2 6 3})\end{array}$ & $\begin{array}{c}\text { Cluster 5 } \\
(\mathbf{n = 1 4 2})\end{array}$ \\
\hline $\mathrm{LSE}_{\mathrm{p}}$ & 84 & 73 & 72 & 74 & 63 \\
\hline $\mathrm{GI}$ & 235 & 172 & 208 & 203 & 181 \\
\hline $\mathrm{GAL}$ & 117 & 108 & 88 & 114 & 84 \\
\hline $\mathrm{PLME}$ & 16 & 15 & 15 & 15 & 13 \\
\hline $\mathrm{ELR}$ & 10 & 12 & 11 & 11 & 9 \\
\hline $\mathrm{IE}_{\mathrm{p}}$ & .74 & .57 & .59 & .61 & .47 \\
\hline $\mathrm{AP}_{\mathrm{p}}$ & .70 & .57 & .57 & .58 & .45 \\
\hline $\mathrm{OC}_{\mathrm{p}}$ & .71 & .66 & .68 & .70 & .61 \\
\hline $\mathrm{CE}$ & .36 & .34 & .33 & .36 & .35 \\
\hline
\end{tabular}

Cluster 1 (type I) is the smallest in its number $(\mathrm{n}=49)$, but satisfies the requirements of the minimum acceptable number of options. The subjects of this type are endowed with high levels of social expectations of personality ( $\mathrm{LSE}_{\mathrm{p}}, 94-84$ ), high levels of general internality (GI, 263235), high levels of general awareness of life (GAL, 123-117), high levels of the projected mobilizing efforts (PLME, 20-16), average expected level of results (ELR, 9-10), the average level of internality $\left(\mathrm{IE}_{\mathrm{p}}, .82-.74\right)$, average level of activeness $\left(\mathrm{AP}_{\mathrm{p}}, .81-.70\right)$, high level of openness $\left(\mathrm{OC}_{\mathrm{p}}, 1.00-.71\right)$, average level of the coefficient of expectations (CE, .18-.36). Important characteristics of this type of expectations are those that attribute it to a high level of social expectations, and in their content peculiarities, the expectations of such subjects are internal, active and open.

Cluster 2 (type II) also has a small number $(\mathrm{n}=58)$. The subjects of this type are endowed with the average level of social expectations of personality (LSEp, 83-73), low level of general internality (GI, 135172), indicators of average and high levels of general awareness of life 
(GAL, 124-108), average level of the projected mobilizing efforts (PLME, 14-15), indicators of average and high expected level of results (ELR, 14-12), low level of internality (IEP, .64-.57), low level of activeness (APp, .66-.57), openness (OCp, 1.00-.66), average and high levels of the coefficient of expectations (CE, .70-.34).

Cluster 3 (type III) combines an average group of subjects with a total number $(\mathrm{n}=92)$. The subjects of this type are endowed with the average level of social expectations of personality (LSEp, 82-72), average and high levels of general internality (GI, 227-208), low level of general awareness of life (GAL, 47-88), average and high levels of the projected mobilizing efforts (PLME, 20-15), indicators of average and high expected level of results (ELR, 14-11), low level of internality (IEP, .69-.59), low activeness (APP, .61-. 57), openness (OCp, 1.00-.68), average level of the coefficient of expectations (CE, .16-.33).

Cluster 4 (type $I V)$ is the largest in its number $(\mathrm{n}=263)$. Students in this type also have the average level of social expectations of personality (LSEp, 71-74), average level of general internality (GI, 208203), average and high levels of general awareness of life (GAL, 155114), low and average levels of the projected mobilizing efforts (PLME, 18-15), average and high expected level of results (ELR, 15-11), low level of internality (IEP, .64- .61), low level of activeness (APP, .56- .58), openness (OCp, 1.00-.70), average level of the coefficient of expectations (CE, .54-.36). It is important to note that clusters II, III, IV combine the average level of social expectations of personality, and the next division is carried out under general internality and the general awareness of life. A characteristic feature of three clusters is internality, activeness and openness of social expectations.

Cluster 5 (type $V$ ) brings together a large number of respondents in total $(n=142)$. The subjects of this type have low level of social expectations of personality (LSEp, 48-63), low and average levels of general internality (GI, 153-181), low level of general awareness of life (GAL, 61-84), low and average levels of the projected mobilizing efforts (PLME, 11-13), low expected level of results (ORP, 3-9), externality (IEP, .14-.47), passiveness (APp, .16-.45), closeness (OCp,. 60-.61), average level of the coefficient of expectation (CE, .41-.35).

Important characteristics of this type of expectations are those that attribute it to low level of social expectations, with low expected level of results. According to their content peculiarities, the expectations of such 
subjects are external, passive and closed. Thus, $k$-means clustering showed the original union of the sample of five clusters studied and allowed to speak about five types of social expectations of the individual.

Realistic type is characterized by high level of social expectations of subjects with high indicators of subjective control and general awareness of life. They have high level of the projected mobilization of efforts and average level of expected results. Expectations are endowed with high indicators of internality, activeness and passiveness.

Passive-thinking type is characterized by average level of social expectations of subjects with low indicators of subjective control and average and high indicators of general awareness of life. They have average level of the projected mobilizing efforts and average and high level of expected results. Expectations are internal, active and open.

Moderate type is characterised by average level of social expectations of the subjects with average and high levels of subjective control and low level of general awareness of life. The subjects are endowed with indicators of average and high levels of the projected mobilizing efforts and expected level of results. Expectations are internal, active and open.

Active-thinking type is characterised by average level of social expectations studied with indicators of average level of subjective control and average and high levels of general awareness of life. Students of this type have indicators of low and average level of the projected mobilizing efforts, but average and high expected level of results. Social expectations are internal, active and open.

Unrealistic type is characterised by low level of social expectations of the subjects with low and average levels of subjective control, and low level of general awareness of life. The students of this type have indicators of low and average levels of projected mobilizing efforts, and low expected level of results. Social expectations of the subjects are external, passive and closed.

Obtained and analysed complexes of the studied indicators or visual taxonomy or classification (typology) make it possible to confirm the existence of five types of social expectations of student youth, and indicate the legality of such distribution. Let's show on fig. 1 a structure of types of social expectations of student youth. 


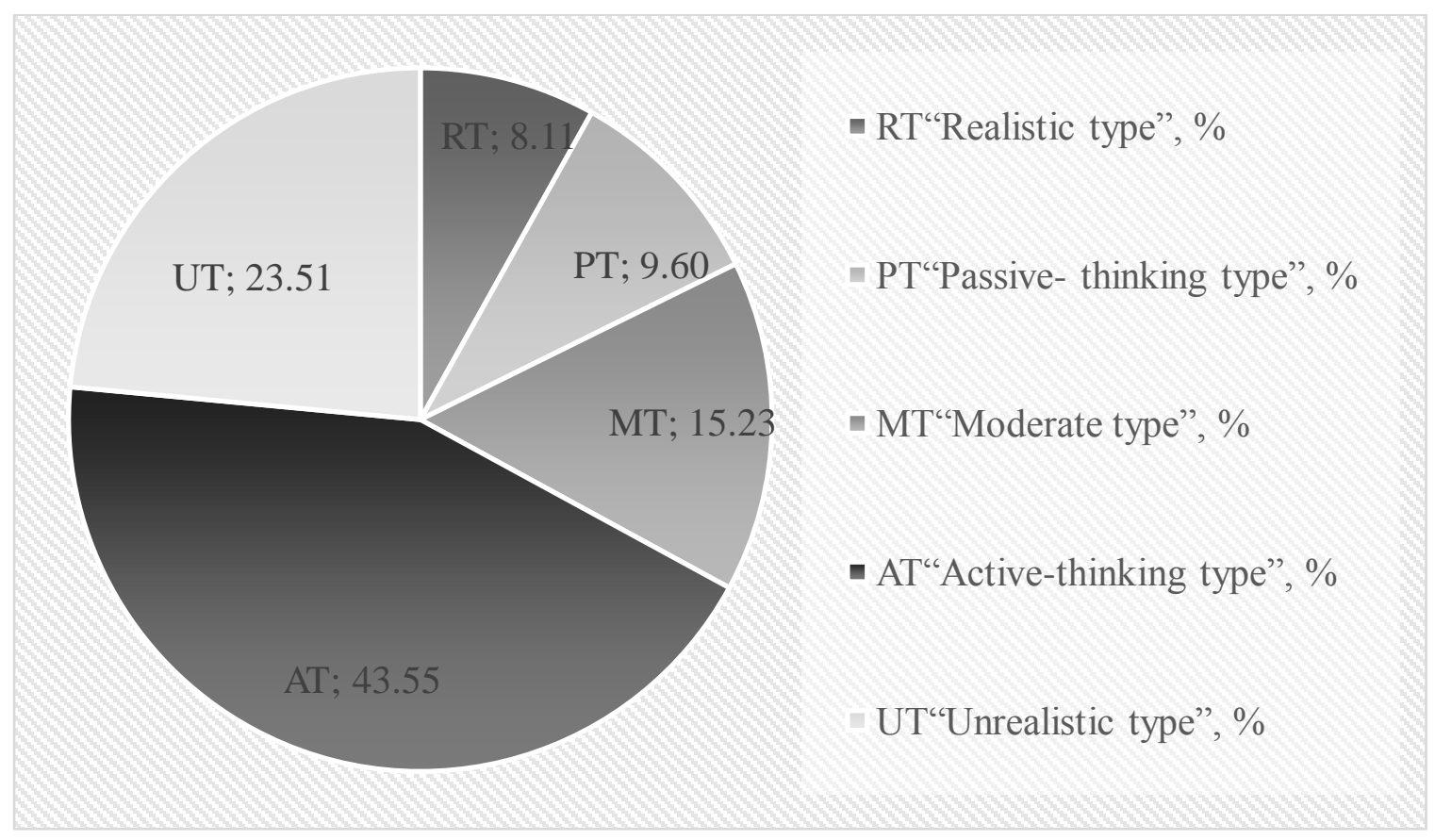

Fig. 1. Structure of types of social expectations of student youth

Let's show empirical results of distribution of types of social expectations among students in the sample population in the table 5.

Table 5

Empirical results of the distribution of types of social expectations of student youth $(n=604)$

\begin{tabular}{|c|c|c|c|c|c|c|c|c|}
\hline \multirow[t]{2}{*}{ 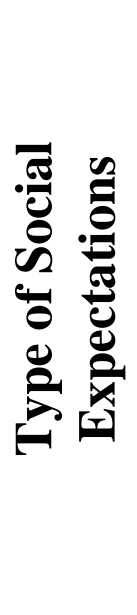 } & \multicolumn{2}{|c|}{$\begin{array}{c}\text { KSU } \\
(n=245)\end{array}$} & \multicolumn{2}{|c|}{$\begin{array}{c}\text { KNTU } \\
(\mathbf{n}=\mathbf{1 2 3})\end{array}$} & \multicolumn{2}{|c|}{ 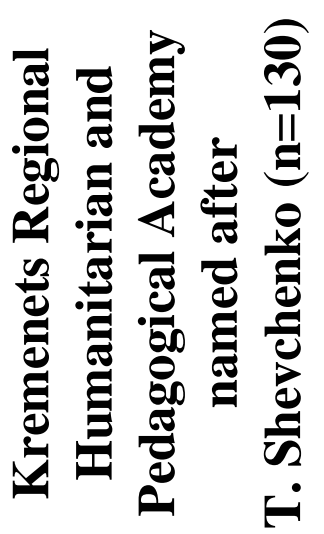 } & \multicolumn{2}{|c|}{$\begin{array}{c}\text { CSPU named } \\
\text { after } \\
\text { V. Vynnyche } \\
\text { nko }(n=106)\end{array}$} \\
\hline & n & $\%$ & $\mathbf{n}$ & $\%$ & $\mathbf{n}$ & $\mathbf{n}$ & $\mathbf{n}$ & $\%$ \\
\hline RT & 18 & 7.35 & 11 & 8.94 & 10 & 7.69 & 10 & 9.43 \\
\hline PT & 22 & 8.98 & 17 & 13.82 & 14 & 10.77 & 5 & 4.72 \\
\hline MT & 33 & 13.47 & 21 & 17.07 & 24 & 18.46 & 14 & 13.21 \\
\hline AT & 102 & 41.63 & 58 & 47.16 & 57 & 43.85 & 46 & 43.39 \\
\hline UT & 70 & 28.57 & 16 & 13.01 & 25 & 19.23 & 31 & 29.25 \\
\hline
\end{tabular}


The empirical results of the distribution of types of social expectations among the students of four higher educational establishments show that the social expectations Realistic type are most represented in the studied the CSPU named after V. Vynnychenko (9.43\%), the least at the KSU (7.35\%). In general, indicators of this type of expectations are equally distributed among all higher educational establishments. According to social expectations, the most represented in the researches of the KNTU (13.82\%), the least in the CSPU named after V. Vynnychenko (4.72\%). In the next type of social expectations Moderate type, we state the highest rates in Kremenets Regional Humanitarian and Pedagogical Academy named after T. Shevchenko $(18.46 \%)$ and the lowest in the CSPU named after V. Vynnychenko $(13.21 \%)$. Active thinking type of social expectations is most represented in the researches of the KNTU (47.16\%), the least in the KSU (41.63\%). In the fifth type of social expectations - the Unrealistic type, we note the highest figures in the CSPU. V. Vynnychenko $(29.25 \%)$ and the lowest in the KNTU $(13.01 \%)$. We can say that the social and personal determinants, level of self-organization of educational and professional activities and the socio-cultural space have a decisive influence on the type of student's expectations.

The first four types of expectations are endowed with internal, active and open properties. Passive-thinking, Moderate, Active types are kinds of specification of the average level of social expectations with variants of content peculiarities. The high indicators of Unrealistic type, which are characterized by low levels of social expectations, subject control, and general awareness of life in conjunction with externality, passiveness and closeness of expectation properties, are alarming. The distribution of the expectation factor for all types is equal. We explain the prevailing indicators of type $\mathrm{V}$ by primarily social and personal determinants, affecting the type of expectations, and only then the pressure of society and other social influences.

\section{CONCLUSIONS}

It is determined that social and personal determinants, the level of self-organization of educational and professional activities and the sociocultural space of higher educational establishments have a significant influence on the psychological content parameters, properties and types of social expectations of student youth. Empirical results and 
substantiation of measurements of expectations showed the legitimacy of the selected indicators of social expectations. The sequence of clustering from the parameters characterizing the socio-psychological determinants of personality expectations to the parameters that outline the social dimension of the expectations of student youth has provided a possibility of establishing cause-effect relationships of types of expectations, and has allowed to substantiate the relationships of personal and social dimensions of the expectations of student youth, which gives reason to confirm that the hypotheses were confirmed.

The prospects for further scientific research are seen in the methodological substantiation and creation of the general typology of social expectations.

\section{SUMMARY}

The psychological content parameters, properties, types of social expectations of student youth were investigated. The sample consisted of students of four higher educational establishments in Ukraine $(n=604)$. Levels of social expectations of students are determined. The prevailing properties of expectations in the current situation of educational and professional activity are determined. The clustering of the studied volume of data is methodologically substantiated and implemented. Research methods: content analysis, tests with standardized questionnaires, factor analysis, by $k$-means clustering. The structure of types of social expectations of student youth is presented. The key in this structure are realistic $(8.11 \%)$ and active types $(43.55 \%)$ of social expectations. The results obtained can be of interest to the organizers of student government, heads of higher educational establishments, all who study the psychological patterns of this social phenomenon.

\section{REFERENCES}

1. Бобнева М. И. Социальные нормы и регуляция поведения: монография. М., 1978. $311 \mathrm{c.}$

2. Засєкіна Л. В. Психолінгвістична діагностика. Луцьк, 2008. $188 \mathrm{c}$.

3. Леонтьев Д. А. Тест смысложизненных ориентаций (СЖО). 2-е изд. М., 2000. 18 с.

4. Осадько О. Ю. Соціальні очікування учнів щодо педагогапрофесіонала та рефлексування цих очікувань вчителями. 
Українська психологія: сучасний потенціал : зб. наук. праць: В 3 т. К., 1996. Т. 2. С. 284-293.

5. Психологическая диагностика. Методология: уровень притязаний личности. Methodology: the level of personality claims. URL : https://sites.google.com/site/test $300 \mathrm{~m} / 16 \mathrm{pfa}$

6. Попович I. С. Визначення типів соціальних очікувань методом кластерного аналізу. Науковий вісник Херсонського державного університету. Серія : психологічні науки : зб. наук. праць ХДУ / за ред. О. С. Блинової. Херсон, 2017. Вип. 1. Т. ІІ. C. $160-166$.

7. Попович І. С. Психологія соціальних очікувань особистості : автореф. дис. ... д-ра психол. наук : 19.00.05. Сєвєродонецьк, 2017. $40 \mathrm{c}$.

8. Попович I. С. Типологічні особливості очікувань. Науковий вісник Херсонського державного університету. Серія : психологічні науки : зб. наук. праць ХДУ / За ред. О. Є. Блинової. Херсон, 2014. Вип. 1. Т. II. С. 64-70.

9. Lloyd S. Least square quantization in PCM's. Bell Telephone Laboratories Paper, 1957. P 211-227.

10. Rotter J. Generalized expectancies for internal versus external control of reinforcement. Psychological Monographs: General and Applied, 80(1), $1966 . \quad$ P. $1-28 . \quad-\quad$ URL : http://dx.doi.org/10.1037/h0092976

11. Tryon R. C. Cluster analysis. London, 1939. 139 p.

12. WMA Declaration of Helsinki. Ethical Principles for Medical Research Involving Human Subjects. URL: http://www.wma.net/es/ 30publications/10policies /b3/17c.pdf

\section{Information about the author: Popovych I. S.}

Doctor of Psychological Sciences, Associate Professor, Associate Professor of the Department of General and Social Psychology Kherson State University 27, Universytetska str., Kherson, 73003, Ukraine 